\title{
Intimate partner violence during pregnancy: analysis of prevalence data from 19 countries
}

\section{Karen M Devries, Sunita Kishor, Holly Johnson, Heidi Stöckl, Loraine J Bacchus, Claudia Garcia-Moreno \& Charlotte Watts}

To cite this article: Karen M Devries, Sunita Kishor, Holly Johnson, Heidi Stöckl, Loraine J Bacchus, Claudia Garcia-Moreno \& Charlotte Watts (2010) Intimate partner violence during pregnancy: analysis of prevalence data from 19 countries, Reproductive Health Matters, 18:36, 158-170, DOI: 10.1016/S0968-8080(10)36533-5

To link to this article: https://doi.org/10.1016/S0968-8080(10)36533-5

\section{(c) 2010 Reproductive Health Matters}

\section{Published online: 24 Nov 2010.}

Submit your article to this journal $₫$

\section{Џ Article views: 5172}

\section{Q View related articles 두}

4 Citing articles: 190 View citing articles 주다. 


\title{
Intimate partner violence during pregnancy: analysis of prevalence data from 19 countries
}

\author{
Karen M Devries, ${ }^{\text {a }}$ Sunita Kishor, ${ }^{b}$ Holly Johnson, ${ }^{\mathrm{c}}$ Heidi Stöckl, ${ }^{\mathrm{d}}$ Loraine J Bacchus, ${ }^{\mathrm{e}}$ \\ Claudia Garcia-Moreno, ${ }^{f}$ Charlotte Watts ${ }^{g}$ \\ a Lecturer, Gender, Violence and Health Centre, London School of Hygiene and Tropical Medicine, London UK. \\ E-mail: karen.devries@Ishtm.ac.uk \\ b Senior Gender Advisor, Measure DHS, ICF Macro, Calverton MD, USA \\ c Associate Professor, Department of Criminology, University of Ottawa, Canada \\ d Research Fellow, Gender, Violence and Health Centre, London School of Hygiene and Tropical \\ Medicine, London UK \\ e Lecturer, Gender, Violence and Health Centre, London School of Hygiene and Tropical Medicine, London UK \\ f Coordinator, Gender, Rights, Sexual Health and Adolescence, Department of Reproductive Health and \\ Research, World Health Organization, Geneva, Switzerland \\ g Professor, Gender, Violence and Health Centre, London School of Hygiene and Tropical Medicine, London UK
}

\begin{abstract}
We aimed to describe the prevalence of intimate partner violence (IPV) during pregnancy across 19 countries, and examine trends across age groups and UN regions. We conducted a secondary analysis of data from the Demographic and Health Surveys (20 surveys from 15 countries) and the International Violence Against Women Surveys (4 surveys from 4 countries) carried out between 1998 and 2007. Our data suggest that intimate partner violence during a pregnancy is a common experience. The prevalence of IPV during pregnancy ranged from approximately $2.0 \%$ in Australia, Cambodia, Denmark and the Philippines to $13.5 \%$ in Uganda among ever-pregnant, ever-partnered women; half of the surveys estimated prevalence to be between 3.9 and $8.7 \%$. Prevalence appeared to be higher in African and Latin American countries relative to the European and Asian countries surveyed. In most settings, prevalence was relatively constant in the younger age groups (age 15-35), and then appeared to decline very slightly after age 35. Intimate partner violence during pregnancy is more common than some maternal health conditions routinely screened for in antenatal care. Global initiatives to reduce maternal mortality and improve maternal health must devote increased attention to violence against women, particularly violence during pregnancy. (C2010 Reproductive Health Matters. All rights reserved.
\end{abstract}

Keywords: intimate partner violence, pregnancy, maternal health

NTIMATE partner violence (IPV) is the most common form of violence against women worldwide. $^{1-4}$ It can occur during both pregnancy and the perinatal period, and is increasingly being recognised as an important risk factor for adverse health outcomes for both mother and newborn. Established direct health effects of physical intimate partner violence during pregnancy include increased likelihood of miscarriage, ${ }^{5}$ premature labour or delivery, ${ }^{6}$ low birthweight, ${ }^{7,8}$ higher levels of depression during and after pregnancy ${ }^{9}$ and injury. ${ }^{10}$ Indirect health effects include substance abuse, ${ }^{11}$ delay in seeking antenatal care, ${ }^{12}$ insufficient weight gain during pregnancy ${ }^{13}$ and reduced levels of breastfeeding. ${ }^{14}$

Knowing the prevalence of intimate partner violence during pregnancy is the first step in helping to inform the development and implementation of interventions to prevent and treat 
sequelae. Antenatal care provides a potentially important window of opportunity for identifying women experiencing violence during pregnancy. For many women in low resource settings, this will be their only point of contact with health care providers. Ideally, women will be seen four times during a pregnancy and once post-partum, and the possibility of follow-up therefore offers an ideal setting for addressing issues of abuse. Providing support on a repeated basis can potentially help women reduce their risk of violence and its consequences, as has been demonstrated in intervention studies in the USA ${ }^{13}$ and Hong Kong. ${ }^{14}$

Comparable population-based data on the prevalence of intimate partner violence during pregnancy are lacking. Available estimates vary widely, from about 3\% ${ }^{15}$ to $30 \%,{ }^{1,16-18}$ Most studies on prevalence have come from small clinical samples in maternity wards, ${ }^{16}$ which often serve particular patient groups and communities, such as immigrant or minority groups, ${ }^{19}$ rural communities, ${ }^{20}$ adolescents, ${ }^{21}$ and women from affluent areas. ${ }^{22}$ A number of other studies include participants from rural and urban areas of the USA,${ }^{23}$ Canada, ${ }^{24}$ Peru, ${ }^{25}$ Mexico, ${ }^{17}$ Rwanda, ${ }^{26}$ Nigeria, ${ }^{27}$ Saudi Arabia, ${ }^{28}$ Iran, ${ }^{16}$ as well as from India, ${ }^{29}$ Pakistan, ${ }^{30} \mathrm{UK},{ }^{15}$ and New Zealand. ${ }^{31}$

Studies vary greatly in respect to the survey methods employed, which include face-to-face, telephone, computer-based and questionnaire interviews, which may affect response rates. ${ }^{23,32}$ A large number of studies have based their measurement of violence during pregnancy on nonvalidated assessment tools, and differ with respect to the range of potential perpetrators included. Some studies ask about violence inflicted during pregnancy by any perpetrator, ${ }^{24,30}$ while others focus solely on asking about violence by intimate partners. ${ }^{31}$ Other factors which differ across research studies include the time periods explored; for example, some focus on intimate partner violence in any pregnancy, ${ }^{31}$ some on the last pregnancy, ${ }^{23}$ others in the previous year among pregnant women, ${ }^{26}$ or at different time points during the pregnancy. ${ }^{15,33}$ Additionally, data on the prevalence of intimate partner violence during pregnancy are often presented separately from data on other forms of intimate partner violence, making it difficult to discern if patterns are distinct.

While these studies have been useful for putting intimate partner violence during pregnancy on the public health policy agenda in their respective countries, there remains a need for population-based data using validated and standardized measures of intimate partner violence during pregnancy.

\section{Methods}

To find out the prevalence of intimate partner violence during pregnancy, we conducted a secondary analysis and examined trends by age and region of cross-sectional household data from the Demographic and Health Surveys (DHS, 20 surveys in 15 countries) and the International Violence against Women Surveys (IVAWS, 4 surveys in 4 countries), which cover four global regions between 1998 and 2007. Survey information is outlined in Table 1.

\section{DHS characteristics}

The Demographic and Health Surveys (DHS) are carried out at approximately five-year intervals in a range of mainly low- and middle-income countries. $^{34}$ These surveys use largely standardized questionnaires and methodologies and cover a range of topics, including demographics; reproductive, maternal and child health; sexual behaviour and nutrition. In-country organizations (usually National Statistical offices) are responsible for implementing the surveys, with technical assistance from Macro International and major funding from the US Agency for International Development (USAID). In the late 1990s, a standardized module of questions on domestic violence was developed; it has since been added to the DHS in 27 countries. Twenty surveys in 15 of these countries provide information on the prevalence of violence during pregnancy.

\section{Sampling}

The surveys are administered to eligible individuals in nationally representative samples of households in each country. Sample selection is multi-stage, with census enumeration areas selected in the first stage with probability proportional to size. Households are selected randomly from a completed listing of households within the selected enumeration areas. All women aged 15-49 in sample households are eligible to be interviewed. ${ }^{35}$ The domestic violence module is typically administered in a sub-sample of selected households, to one randomly selected 


\section{Table 1. Survey characteristics}

\begin{tabular}{|c|c|c|c|}
\hline Country & Year & $\begin{array}{l}\text { Sample } \\
\text { size }^{a}\end{array}$ & $\begin{array}{l}\text { Response } \\
\text { rate }^{b, c}\end{array}$ \\
\hline \multicolumn{4}{|l|}{ DHS } \\
\hline Azerbaijan & 2006 & 5,803 & $98 \%$ \\
\hline Cambodia & 2000 & 2,460 & $99 \%$ \\
\hline Cambodia & 2005 & 2,938 & $98 \%$ \\
\hline Cameroon & 2004 & 3,349 & $94 \%$ \\
\hline Colombia & 2000 & 11,585 & $93 \%$ \\
\hline Colombia & 2005 & 41,344 & $93 \%$ \\
\hline Dominican Republic & 1999 & 10,307 & $90 \%$ \\
\hline Dominican Republic & 2002 & 8,868 & $93 \%$ \\
\hline Dominican Republic & 2007 & 955 & $93 \%$ \\
\hline DR Congo & 2007 & 3,507 & $97 \%$ \\
\hline Haiti & 2000 & 3,575 & $98 \%$ \\
\hline Haiti & 2005 & 3,433 & $99 \%$ \\
\hline Jordan & 2000 & 3,476 & $98 \%$ \\
\hline Malawi & 2004 & 9,863 & $96 \%$ \\
\hline Moldova & 2005 & 5,758 & $95 \%$ \\
\hline Nicaragua & 1998 & 8,508 & $92 \%$ \\
\hline Rwanda & 2005 & 4,066 & $98 \%$ \\
\hline Uganda & 2006 & 2,169 & $95 \%$ \\
\hline Zambia & 2007 & 5,259 & $97 \%$ \\
\hline Zimbabwe & 2005 & 6,351 & $90 \%$ \\
\hline \multicolumn{4}{|l|}{ IVAWS } \\
\hline Australia & 2002 & 6,677 & $39 \%$ \\
\hline Denmark & 2003 & 3,589 & $52 \%$ \\
\hline Mozambique & 2004 & 2,015 & $96 \%$ \\
\hline Philippines & 2005 & 2,602 & $99 \%$ \\
\hline \multicolumn{4}{|c|}{$\begin{array}{l}\text { a In DHS, number of eligible women for domestic violence } \\
\text { module subsample }\end{array}$} \\
\hline \multicolumn{4}{|c|}{$\begin{array}{l}\text { b In DHS, response rate for eligible women for the whole } \\
\text { survey. Between } 96-100 \% \text { of women who completed the } \\
\text { whole survey and were also eligible for the domestic } \\
\text { violence module completed the module. }\end{array}$} \\
\hline
\end{tabular}

eligible woman per household, in accordance with World Health Organization (WHO) ethical and safety guidelines. ${ }^{35,36}$ Homeless women and those living in shelters or institutions are excluded in all countries.

\section{Interviewer training}

Interviewers receive several weeks of rigorous training for administering the DHS survey; in countries where the domestic violence module is fielded, interviewers receive additional training on linkages between gender, violence and health; building rapport with the respondent; ensuring privacy and what to do when privacy is not possible or is interrupted; and providing information on sources of assistance. In the DHS, women are interviewed only by women.

\section{IVAWS characteristics}

The International Violence Against Women Survey (IVAWS) is a single-round survey which has been completed in nine countries. The IVAWS project is co-ordinated internationally by the European Institute for Crime Prevention and Control, with inputs from the United Nations Office on Drug and Crime, United Nations Interregional Crime and Justice Research Institute, and Statistics Canada. It has been conducted by independent investigators in each country, and each country participates on a self-funded basis. In contrast to the DHS, these surveys are specifically designed to measure the prevalence of intimate partner and other forms of violence against women. All nine surveys included questions on violence during pregnancy and four contained sufficient additional information to permit estimates to be made of the prevalence of intimate partner violence among women with children.

\section{Sampling}

Telephone surveys were conducted by random digit-dialling or sampling from telephone directories. Face-to-face surveys were conducted by two-stage cluster sampling: the first stage was the selection of cities or provinces; the second stage was the selection of districts within these cities or provinces. Households were selected using a random walk method. All women aged 18-69 years were eligible for inclusion; only one woman per household was selected in accordance with the ethical principles identified by $\mathrm{WHO}^{36}$ and Johnson et al. ${ }^{4}$ In households with more than one eligible woman, the woman with the next birthday was selected to participate. Surveys were conducted either face-to-face or by telephone, a decision that was left to project coordinators in each country. In some countries, therefore, results do not reflect the experiences of women in households without landlines or women with mobile phones only. Homeless 
women and those living in shelters or institutions were excluded in all countries.

\section{Interviewer training}

National coordinators from each country attended a group session to discuss issues related to survey implementation, including interviewer training and sensitization. In each country, female interviewers were selected based on their having some awareness about violence against women, and were provided with additional standardized training regarding the effects of violence against women, common myths about violence, ways to encourage honest disclosure of relevant experiences, and the importance of providing emotional support to women disclosing violence by referring them to local agencies. ${ }^{4}$

\section{Definitions of violence and partnership status}

The definitions of violence and partnership used in the DHS and IVAWS are outlined in Tables 2 and 3; items constituting severe abuse are starred. In the DHS, women who have ever been pregnant are asked whether they have ever been hit, slapped, kicked or physically hurt by anyone, and if yes, who that person was. Women are counted as having experienced intimate partner violence during pregnancy if the person perpetrating the violence was a current or past husband or cohabiting partner. In IVAWS, women who reported experiencing any form of physical and/or sexual intimate partner violence were then asked if any of these acts had ever occurred while they were pregnant.

\section{Statistical analysis}

The prevalence of each form of intimate partner violence was calculated separately for each survey and country. DHS estimates are weighted to adjust for non-response, selection of one woman per household and to achieve national representativeness. Standard errors for DHS estimates are corrected for the complex sampling schemes employed (calculated using Taylor linearization). IVAWS estimates are weighted according to the age profiles provided by the UN Statistical Division for the year of the survey to adjust for bias due to non-response.

The prevalence of intimate partner violence during pregnancy in IVAWS could not be calculated directly, as the surveys did not collect information on the number of ever-pregnant women in their samples. To create estimates, we used information within the survey on whether or not a woman had children residing in the household as a proxy for ever-pregnancy. This excluded women with no living children and those whose children were no longer residing in the household.

In this paper, we present descriptive data on the prevalence of intimate partner violence during pregnancy, and compare this with prevalence of

Table 2. Demographic and Health Survey definitions

\begin{tabular}{|c|c|c|c|}
\hline Female population & Intimate partner definition & Form of IPV & Violence definition \\
\hline $\begin{array}{l}\text { Ever-married/cohabited } \\
\text { women aged 15-49 }\end{array}$ & $\begin{array}{l}\text { Current (for currently married/ } \\
\text { cohabiting women) or last } \\
\text { husband or partner (for } \\
\text { currently widowed, divorced } \\
\text { or separated women) }\end{array}$ & $\begin{array}{l}\text { Lifetime, past year, } \\
\text { and severet }\end{array}$ & $\begin{array}{l}\text { Experience of the following acts by } \\
\text { an intimate partner ever in the } \\
\text { relationship: pushed, shaken or had } \\
\text { something thrown at you; slapped; arm } \\
\text { twisted or hair pulled; " punched with a } \\
\text { fist or something that could hurt; } \\
{ }^{*} \text { kicked, dragged, or beaten; * choked or } \\
\text { burned on purpose; *threatened with } \\
\text { knife, gun or other weapon; *attacked } \\
\text { with knife, gun or other weapon. }\end{array}$ \\
\hline $\begin{array}{l}\text { Ever-married/co-habited, } \\
\text { ever-pregnant women } \\
\text { aged 15-49 }\end{array}$ & $\begin{array}{l}\text { Any husband or cohabiting } \\
\text { partner }\end{array}$ & $\begin{array}{l}\text { IPV during } \\
\text { pregnancy }\end{array}$ & $\begin{array}{l}\text { During any pregnancy, ever being: hit; } \\
\text { slapped; kicked; or physically hurt by } \\
\text { any other means by a husband or } \\
\text { cohabiting partner. }\end{array}$ \\
\hline
\end{tabular}

† There are minor variations in the list and groupings of acts included in some DHSS.

* Experience of any of these acts was coded as severe violence. 
Table 3. International Violence Against Women Survey definitions

\begin{tabular}{|c|c|c|c|}
\hline Female population & Intimate partner & $\begin{array}{l}\text { Form of IPV } \\
\text { definition }\end{array}$ & Violence definition \\
\hline $\begin{array}{l}\text { Ever-married/ } \\
\text { cohabited/dated } \\
\text { women, aged 18-69 }\end{array}$ & $\begin{array}{l}\text { Current or former male } \\
\text { partner with whom woman } \\
\text { has been married, } \\
\text { cohabited or dated }\end{array}$ & $\begin{array}{l}\text { Lifetime, past } \\
\text { year, severe }\end{array}$ & $\begin{array}{l}\text { Experience of the following acts by an intimate } \\
\text { partner, since age 16: threatened to hurt you } \\
\text { physically in a way that frightened you; *threw } \\
\text { something at you or hit you with something that hurt } \\
\text { or frightened you; *tried to strangle or suffocate } \\
\text { you, burn or scald you on purpose; *slapped, } \\
\text { kicked, bit or hit you with a fist; * "pushed or grabbed } \\
\text { you or twisted your arm or pulled your hair in a way } \\
\text { that hurt or frightened you; *used or threatened to } \\
\text { use a knife or gun on you; * was physically violent } \\
\text { towards you in a way that I have not already } \\
\text { mentioned; * } \text { forced you into sexual intercourse by } \\
\text { threatening you, holding you down, or hurting you in } \\
\text { some way; *attempted to force you into sexual } \\
\text { intercourse by threatening you, holding you down or } \\
\text { hurting you in some way; *touched you sexually } \\
\text { when you did not want him to in a way that was } \\
\text { distressing to you; * forced or attempted to force you } \\
\text { into sexual activity with someone else, including } \\
\text { being forced to have sex for money or in exchange } \\
\text { for goods; *was sexually violent towards you in a } \\
\text { way that I have not already mentioned. }\end{array}$ \\
\hline $\begin{array}{l}\text { Ever-married/ } \\
\text { cohabited/dated } \\
\text { women, aged 18-69, } \\
\text { in households with } \\
\text { at least one child }\end{array}$ & $\begin{array}{l}\text { Current or former male } \\
\text { partner with whom } \\
\text { woman has been married, } \\
\text { cohabited or dated }\end{array}$ & $\begin{array}{l}\text { IPV during } \\
\text { pregnancy }\end{array}$ & $\begin{array}{l}\text { If a woman answered yes to any of the above } \\
\text { questions, she was asked if any of the above ever } \\
\text { occurred while she was pregnant. }\end{array}$ \\
\hline
\end{tabular}

*Experience of any of these acts was coded as severe violence.

other forms of intimate partner violence (Table 4). The overall prevalence of intimate partner violence during pregnancy is then summarised by survey and UN region (Figure 1). To examine age patterns, we calculated pooled estimates of prevalence and standard error of intimate partner violence during pregnancy for each age group for each region. We used a random effects inverse variance meta-analysis, which weights individual study estimates according to their precision. We plotted these mean prevalence figures by age group and region (Figure 2). Finally, to examine changes in the prevalence of physical intimate partner violence during pregnancy by age group over time, we plotted age-specific prevalence by survey year for four countries which had a DHS conducted in more than one year (Figure 3). Analyses were conducted using STATA 11.0.

\section{Results}

The prevalence of intimate partner violence during pregnancy among ever-pregnant women ranged from approximately 2\% in Australia, Denmark, Cambodia and Philippines to $13.5 \%$ among ever-pregnant women in Uganda (Table 4, Figure 1). Over half of the surveys had a prevalence estimate between 3.8 and 8.8\%. Prevalence appeared to be higher in the African and Latin American countries relative to the European and Asian countries surveyed, although estimates within regions (and countries) were highly variable. 
Table 4. Prevalence of intimate partner violence in 19 countries (23 surveys), 1998-2007a

\begin{tabular}{|c|c|c|c|c|c|c|c|c|c|c|c|}
\hline \multirow[t]{2}{*}{ Country } & \multirow[t]{2}{*}{ Year } & \multirow[t]{2}{*}{$\begin{array}{l}\text { No. ever } \\
\text { pregnant } \\
\text { women }^{b}\end{array}$} & \multicolumn{2}{|c|}{$\begin{array}{c}\text { Physical } \\
\text { t IPV during } \\
\text { pregnancyc }\end{array}$} & \multirow[t]{2}{*}{$\begin{array}{l}\text { No. ever } \\
\text { partnered } \\
\text { women }^{b}\end{array}$} & \multicolumn{2}{|c|}{ Ever IPV } & \multicolumn{2}{|c|}{ Past year IPV ${ }^{d}$} & \multicolumn{2}{|c|}{ Severe IPV } \\
\hline & & & $\%$ & SE & & $\%$ & SE & $\%$ & SE & $\%$ & SE \\
\hline \multicolumn{12}{|l|}{ DHS } \\
\hline Azerbaijan & 2006 & 4,054 & 4.0 & 0.4 & 4,140 & 13.3 & 0.7 & 9.9 & 0.7 & 5.0 & 0.5 \\
\hline Cambodia & 2000 & 2,301 & 2.0 & 0.3 & 2,204 & 17.1 & 0.9 & 15.4 & 0.9 & 9.9 & 0.8 \\
\hline Cambodia & 2005 & 2,239 & 2.8 & 0.4 & 2,188 & 13.6 & 1.1 & 9.4 & 0.8 & 7.2 & 0.8 \\
\hline Cameroon & 2004 & 2,491 & 8.6 & 0.8 & 2,574 & 43.0 & 1.3 & 28.2 & 1.2 & 21.7 & 1.1 \\
\hline Colombia & 2000 & 7,403 & 10.6 & 0.4 & 7,480 & 40.7 & 0.7 & $\ddagger$ & $\neq$ & 22.2 & 0.5 \\
\hline Colombia & 2005 & 24,449 & 8.1 & 0.3 & 24,864 & 39.5 & 0.5 & 22.2 & 0.4 & 22.6 & 0.4 \\
\hline Dominican Republic & 1999 & 714 & 6.5 & 1.1 & 739 & 27.6 & 2.2 & 16.4 & 1.5 & 13.7 & 1.4 \\
\hline Dominican Republic & 2002 & 7,086 & 5.1 & 0.5 & 7,386 & 19.2 & 0.7 & 10.8 & 0.6 & 12.7 & 0.6 \\
\hline Dominican Republic & 2007 & 8,024 & 5.7 & 0.4 & 8,334 & 17.0 & 0.8 & 11.7 & 0.6 & 10.3 & 0.6 \\
\hline DR Congo & 2007 & 2,743 & 9.4 & 0.9 & 2,778 & 64.4 & 1.8 & 63.0 & 1.8 & 38.1 & 1.9 \\
\hline Haiti & 2000 & 2,475 & 5.3 & 0.7 & 2,517 & 26.1 & 1.4 & 20.8 & 1.5 & 15.2 & 1.4 \\
\hline Haiti & 2005 & 2,497 & 4.1 & 0.6 & 2,605 & 19.4 & 1.3 & 17.5 & 1.3 & 11.6 & 0.9 \\
\hline Jordan & 2000 & 3,269 & 5.0 & 0.5 & 3,356 & 22.8 & 1.4 & 14.6 & 1.1 & 10.5 & 0.9 \\
\hline Malawi & 2004 & 8,365 & 3.8 & 0.3 & 8,294 & 27.8 & 0.7 & 19.5 & 0.6 & 13.8 & 0.5 \\
\hline Moldova & 2005 & 4,138 & 6.6 & 0.4 & 4,488 & 24.3 & 0.8 & 14.6 & 0.7 & 11.4 & 0.6 \\
\hline Nicaragua & 1998 & 9,886 & 11.1 & 0.4 & 10,274 & 28.7 & 0.6 & 12.6 & 0.5 & 22.6 & 0.5 \\
\hline Rwanda & 2005 & 2,802 & 8.8 & 0.6 & 2,714 & 32.5 & 1.0 & 18.4 & 0.8 & 18.5 & 0.8 \\
\hline Uganda & 2006 & 1,716 & 13.5 & 1.0 & 1,664 & 57.4 & 1.9 & 44.8 & 1.8 & 39.5 & 1.6 \\
\hline Zambia & 2007 & 4,122 & 9.0 & 0.6 & 4,033 & 49.5 & 1.1 & 43.0 & 1.2 & 23.8 & 0.9 \\
\hline Zimbabwe & 2005 & 4,811 & 5.6 & 0.4 & 4,537 & 35.0 & 1.0 & 30.4 & 0.9 & 21.7 & 0.8 \\
\hline \multicolumn{12}{|l|}{ IVAWS } \\
\hline Australia & 2002 & 6,386 & 2.0 & 0.2 & 6,386 & 26.6 & 0.5 & 4.4 & 0.2 & 19.7 & 0.5 \\
\hline Denmark & 2003 & 3,569 & 1.8 & 0.3 & 3,570 & 22.2 & 0.7 & 1.3 & 0.2 & 17.0 & 0.6 \\
\hline Mozambique & 2004 & 1,781 & 7.3 & 0.7 & 1,781 & 39.5 & 1.1 & 18.0 & 0.9 & 34.0 & 1.1 \\
\hline Philippines & 2005 & 2,183 & 2.0 & 0.3 & 2,183 & 10.2 & 0.6 & 3.2 & 0.4 & 7.7 & 0.6 \\
\hline
\end{tabular}

a All prevalance estimates are weighted and SE estimates adjusted for survey design where appropriate.

b See Table 2 for detailed definitions of ever-partnered, ever-pregnant women.

c For IVAWS, includes sexual and physical IPV.

$d$ For some DHS, widows were not asked about IPV in the past year.

‡ Not asked in Colombia 2000.

The prevalence of lifetime intimate partner violence ranged from $10.7 \%$ in the Philippines to $64.4 \%$ in the Democratic Republic of Congo (DRC) (Table 4). Prevalence of past year intimate partner violence ranged from just over $1 \%$ in Denmark to $63.0 \%$ in the DRC. Severe intimate partner violence over the woman's lifetime ranged from 5.0\% in Azerbaijan to 39.5\% in Uganda. Although the data on lifetime, past year and severe intimate partner violence have slightly different denominators to data on intimate part- ner violence during pregnancy, they suggest that intimate partner violence during pregnancy occurs at lower levels than lifetime and pastyear intimate partner violence. In almost all settings, intimate partner violence during pregnancy also occurs at lower levels than lifetime severe intimate partner violence. The only exception to these patterns was Denmark, where intimate partner violence during pregnancy was more common than severe intimate partner violence and past-year violence. 


\section{Figure 1. Prevalence of physical IPV during pregnancy}

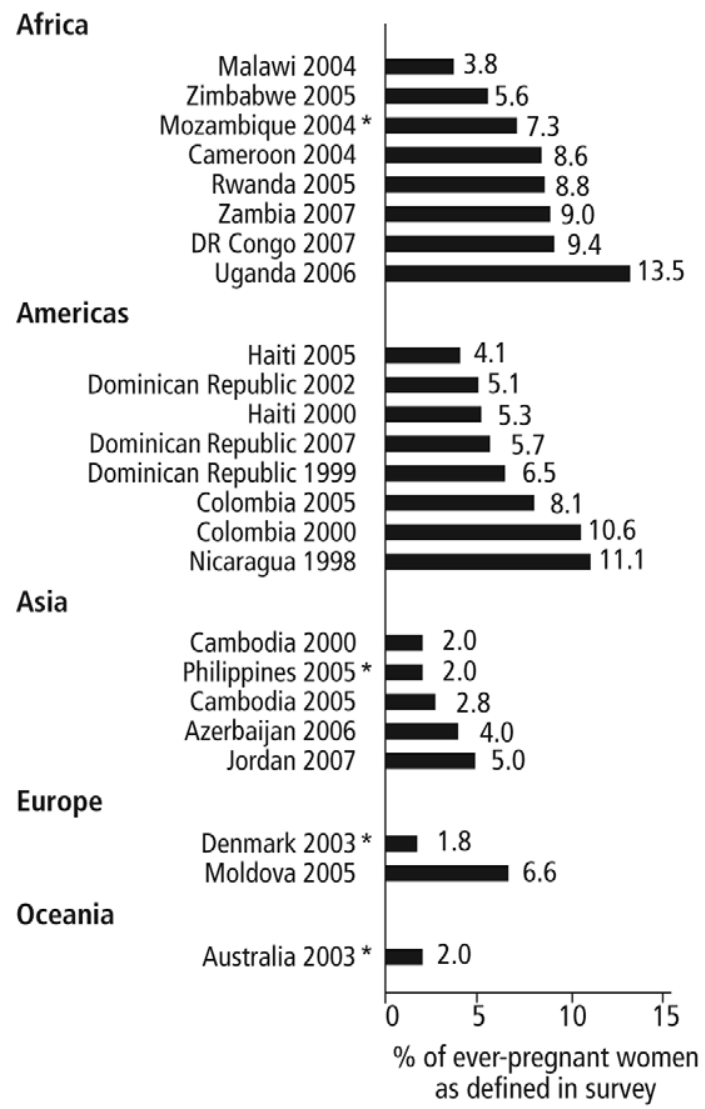

*IVAWS estimates also include sexual IPV during pregnancy.

However, countries with a high prevalence of lifetime severe intimate partner violence do not necessarily also report a proportionately high prevalence of intimate partner violence during pregnancy. Azerbaijan had among the lowest prevalence of lifetime severe intimate partner violence $(5.0 \%)$, but nearly the same prevalence of intimate partner violence during pregnancy (4.0\%). Conversely, Uganda, DRC and Mozambique had among the highest prevalences of severe intimate partner violence $(39.5 \%, 38.1 \%$, and $34.0 \%$, respectively), but lower levels of intimate partner violence during pregnancy $(13.5 \%, 9.4 \%$, and $7.3 \%$, respectively).

The age-specific patterns of having ever experienced intimate partner violence during preg- nancy appear to follow roughly similar patterns across surveys in all settings (Figure 2). Despite the possibility that older women would have more time to potentially be exposed to violence during pregnancy, in nearly all settings the prevalence was relatively constant in the younger age groups (age 15-35), and then declined very slightly in both the African and Latin American countries in the oldest age groups (age 35 and up), although estimates vary somewhat within groups.

Cambodia, Colombia, Dominican Republic and Haiti had more than one DHS in different years. In these studies, 95\% confidence intervals are overlapping, indicating no statistically significant temporal changes in the levels of violence over time within specific age groups (Figure 3). The only exception is Colombia, where the data suggest a trend towards lower prevalence in all age groups in the 2005 versus the 2000 survey.

\section{Discussion}

This is the first analysis of internationally comparable data on the population prevalence of intimate partner violence during pregnancy. Our data suggest that intimate partner violence during a pregnancy is a common experience. However, prevalence varies considerably within and between global regions. Data on age trends show fairly consistent age patterns across regions, with a relatively constant prevalence across younger age groups (up to around age 35 ) and a slight decline after age 35 .

Our data show that prevalence of intimate partner violence during pregnancy remains relatively constant until about age 35, which suggests that in many settings, the violence occurs in a first or early pregnancy. The decline in reported violence during pregnancy in older age groups may be due to recall bias - younger women are probably less prone to recall bias because they are more likely to have experienced intimate partner violence in the past year ${ }^{2}$ and to have been recently pregnant relative to women in older age groups.

However, we cannot rule out the possibility that these age patterns are the result of a cohort effect, where women born in earlier years had a lower risk of intimate partner violence during pregnancy. Although our analysis of age patterns over different survey years within countries did 
Figure 2. Prevalence of physical IPV during pregnancy by region and age $\mathrm{e}^{\mathrm{a}, \mathrm{b}}$

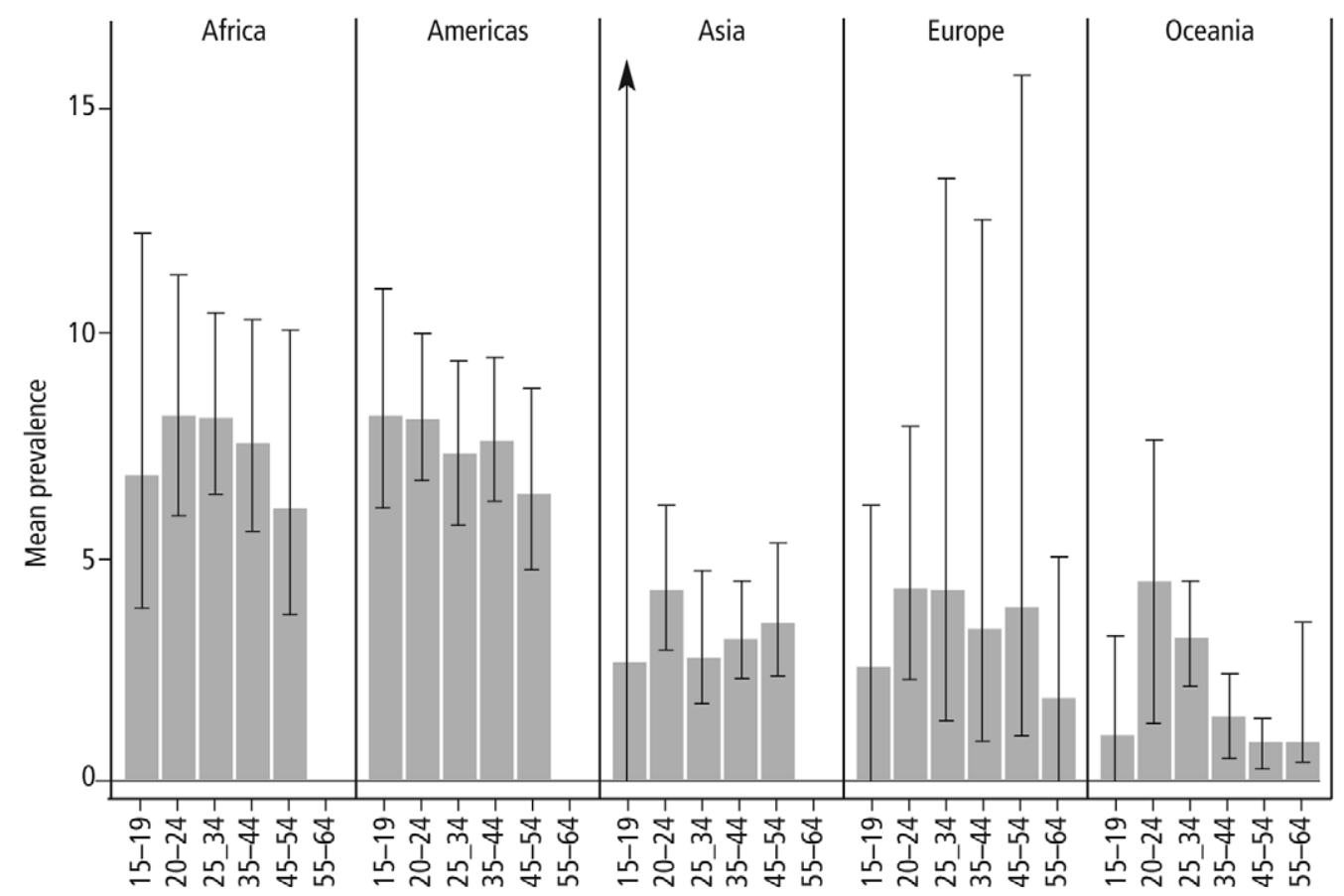

UN regions and age groups

a IVAWS estimates also include sexual IPV during pregnancy.

b DHS estimates include women aged 15-49; estimates for those aged 45-49 are applied to the age group 45-54 in this analysis. IVAWS included those aged 18-69; however, the reported prevalence in those aged 55-69 in Africa and Asia was zero. No IVAWS were conducted in the Americas. The reported prevalence for those aged 65-69 was zero in all regions.

not reveal any clear changes in prevalence within age groups Figure 3), it may be that opposing fertility trends affect prevalence. In many countries, age at first pregnancy is increasing; thus women who do begin childbearing at young ages may represent a more socio-economically disadvantaged group who have a higher risk of intimate partner violence. Fertility is also declining in many countries and women are having first pregnancies at later ages; thus exposure to violence in pregnancy will happen at an older age because pregnancy happens at older ages, relative to previous surveys.

The prevalence figures for intimate partner violence during pregnancy presented here are generally comparable to those found in the literature, including the WHO Multi-Country Study on Women's Health and Domestic Violence against
Women, another internationally comparative population-based survey. In the WHO survey, the levels of violence during pregnancy among ever-pregnant women were highest in rural Peru (27.6\%), rural Tanzania (12.3\%), and rural Bangladesh (12.4\%), and lowest in Japan (1.2\%), Serbia (3.4\%), and rural and urban Thailand (3.8\% and $4.2 \%$, respectively). ${ }^{1}$ These WHO data suggest differences between rural and urban settings in several countries, although not always in a consistent direction.

We found that countries reporting high levels of severe intimate partner violence did not necessarily also report high levels of intimate partner violence during pregnancy, suggesting that cultural factors may be important determinants of the prevalence of intimate partner violence during pregnancy. These could include differences in 
Figure 3. Prevalence of physical IPV during pregnancy by age and year of survey, for countries with data from multiple years
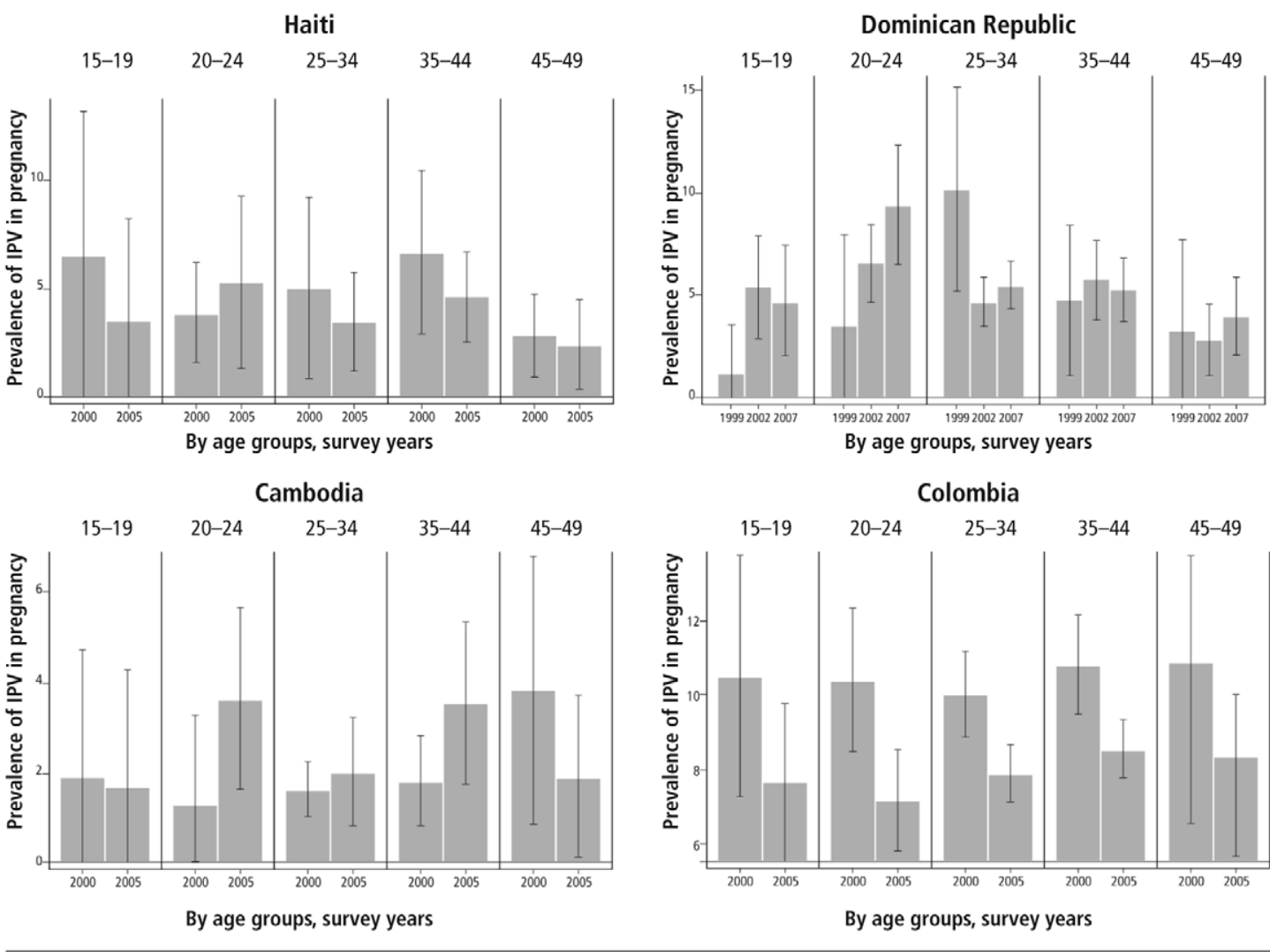

attitudes about wife-beating, egalitarianism in male-female relationships, and male partner beliefs in the centrality of the wife-mother role for women. ${ }^{18}$

Several previous studies have found that violence may be more likely during a first pregnancy, because the stress of transition to parenthood can trigger intimate partner violence during pregnancy, ${ }^{37}$ and because young pregnant women may be less emotionally ready for pregnancy and more economically dependent on their partners. ${ }^{38}$ Other work indicates that violence during pregnancy may simply be a continuation of pre-existing intimate partner violence. The United States Pregnancy Risk Assessment Monitoring System Study indicates that for most US women, violence decreases during pregnancy, but for some women it continues or becomes more severe. ${ }^{39}$ However, in the WHO study in Brazil, Ethiopia and Serbia,

women indicated that intimate partner violence started during pregnancy. ${ }^{1}$

\section{Strengths and limitations}

Although the DHS and IVAWS are internationally comparable, in practice, there are slight methodological variations between the individual surveys, which may limit comparability. For IVAWS, the number of ever-pregnant women was estimated using a proxy variable which captured the number of women with children residing in the household. This is likely to have undercounted the number of ever-pregnant women, thus slightly inflating the prevalence estimates, especially for older women. Response rates were very high for the DHS and IVAWS in most lowand middle-income settings, however the IVAW surveys conducted in higher income settings had lower response rates. Although this is typical of surveys conducted in high-income settings 
and telephone surveys, this limits their population representativeness.

Our estimates include women who may not have attended antenatal care, which is a key limitation of prevalence studies conducted in antenatal clinics in lower income settings. In the least developed countries, one in three women do not receive any antenatal care. ${ }^{40}$ Further, in the WHO study, women in rural Ethiopia, rural Bangladesh and rural Tanzania who had experienced intimate partner violence were significantly less likely to have attended for antenatal care. ${ }^{1}$

All survey data rely on women's reports about their experiences of violence, and so may be subject to recall and response bias. Despite extensive interviewer training and efforts to ensure privacy for respondents in both IVAWS and DHS, women still may not have felt able to disclose experiences of violence during pregnancy; thus, the figures presented are likely to be underestimates. ${ }^{41}$

Although this research provides important information about the global prevalence of intimate partner violence during pregnancy, it also has limited detail about the contexts in which violence occurs. For example, the surveys did not collect detailed information about which pregnancy violence occurred in - yet the findings from a study on violence during pregnancy in Tanzania found that most violence occurred during one pregnancy only. ${ }^{42}$ Similarly, the DHS asked only about physical violence during pregnancy, while IVAWS asked about physical and sexual violence. Detailed information about the impact of emotional violence is not available, although different types of intimate partner violence can have different health consequences for women. ${ }^{43}$

\section{Implications and conclusions}

Our data suggest that violence during pregnancy is more common than several recognized maternal health conditions for which it is current practice to screen during antenatal care. This includes pre-eclampsia, which complicates $2-8 \%$ of pregnancies globally, ${ }^{44,45}$ and gestational diabetes, which has between $1-5 \%$ prevalence in

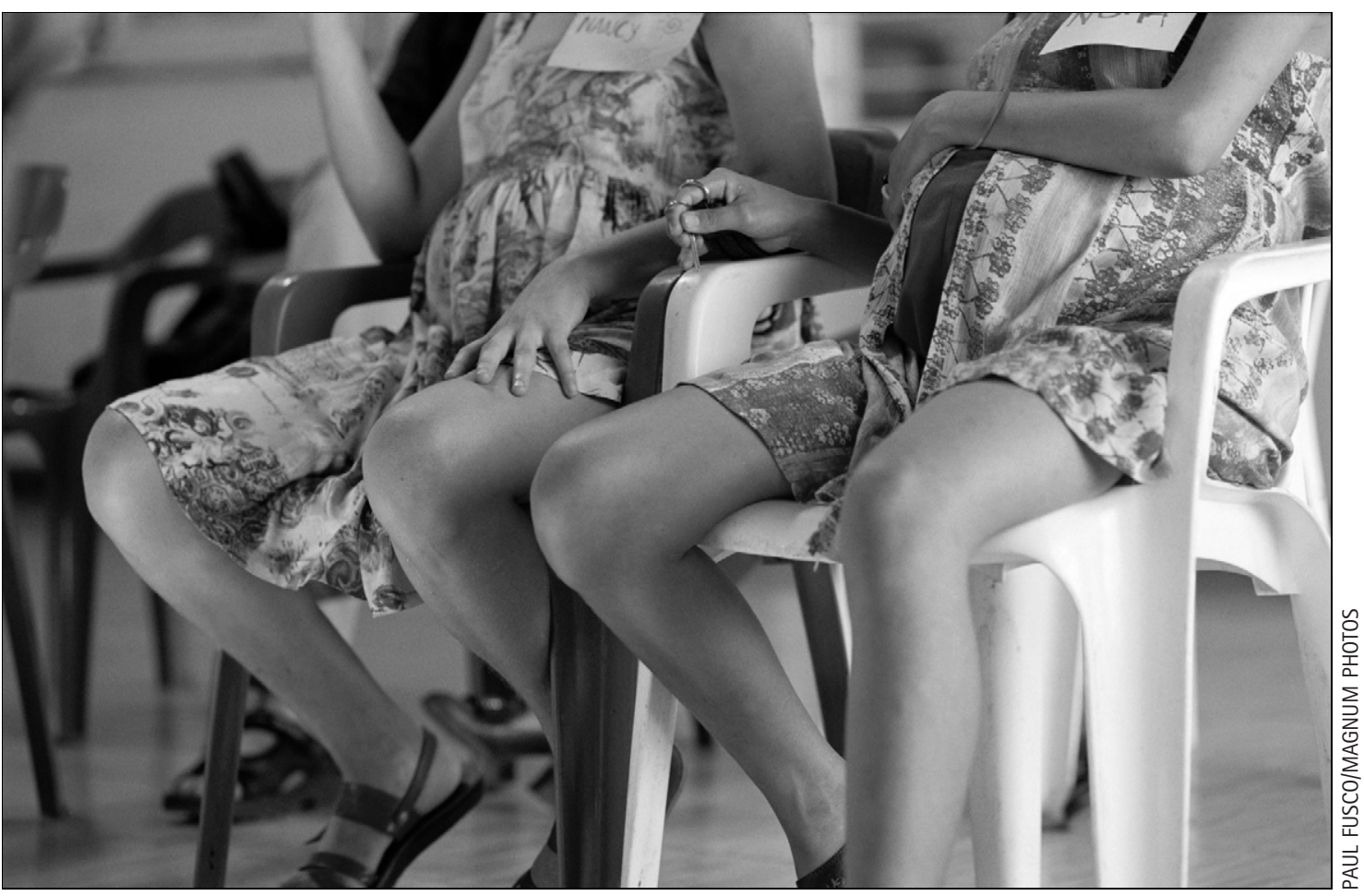

Encuentro con Amor, workshops for young people by Médécins sans Frontières on domestic violence, Cali, Colombia, 1998 
the UK and USA. ${ }^{46}$ Both of these conditions are potentially fatal if left untreated. ${ }^{45}$ Although the extent of maternal mortality, miscarriage and stillbirth associated with intimate partner violence during pregnancy remains unknown, intimate partner violence is a leading cause of death among adult women in the USA ${ }^{47}$ and is associated with maternal mortality in the $\mathrm{UK}^{48}$ Abuse during pregnancy is also associated with kidney infections, suboptimal weight gain, and having lower birthweight babies. ${ }^{49}$

Antenatal care offers a window of opportunity, but more research is needed, in particular to assess the feasibility and effectiveness of interventions that can be integrated into antenatal care in resource-poor settings. ${ }^{44}$ Expansion of antenatal care services, and/or alternate modes of intervention to reach women in low-income settings who do not attend antenatal care, are also crucial.
Women are not immune from violence during pregnancy. Given the prevalence of intimate partner violence during pregnancy and its potential impact on maternal and newborn health, it is important that global initiatives to reduce maternal mortality and morbidity and improve maternal health devote increased attention to violence against women, particularly during pregnancy. More research needs to be undertaken, using comparable methodologies, to both assess the magnitude and nature of the problem and to test potential interventions that can be implemented in resource-poor settings.

\section{Acknowledgements}

We acknowledge USAID for supporting analysis of DHS data through the MEASURE DHS contract GPO-C-00-08-00008-00, and Datla V Raju and Trina Forrester for conducting data analysis patiently and meticulously.

\section{References}

1. García-Moreno C, Jansen HA, Ellsberg M, et al. WHO MultiCountry Study on Women's Health and Domestic Violence against Women: initial results on prevalence, health outcomes and women's responses. Geneva: World Health Organization; 2005.

2. Kishor S, Johnson K. Profiling domestic violence: a multi-country study. Calverton MD: ORC Macro; 2004.

3. Jewkes R. Intimate partner violence: causes and prevention. Lancet 2002; 359(9315):1423-29.

4. Johnson H, Ollus N, Nevala S. Violence against Women: An International Perspective. New York: Springer; 2007.

5. Taft AJ, Watson LF. Termination of pregnancy: associations with partner violence and other factors in a national cohort of young Australian women. Australian and New Zealand Journal of Public Health 2007; 31(2):135-42.

6. Rodrigues T, Rocha L, Barros H. Physical abuse during pregnancy and preterm delivery.
American Journal of Obstetrics and Gynecology 2008;198(2): 171.e1-e6.

7. Valladares E, Ellsberg M, Pena R, et al. Physical partner abuse during pregnancy: a risk factor for low birth weight in Nicaragua. Obstetrics and Gynecology 2002; 100(4):700-05.

8. Murphy CC, Schei B, Myhr TL, et al. Abuse: a risk factor for low birth weight? A systematic review and meta-analysis. Canadian Medical Association Journal 2001;164(11):1567-72.

9. Martin SL, Li Y, Casanueva C, Harris-Britt A, et al. Intimate partner violence and women's depression before and during pregnancy. Violence against Women 2006;12(3):221-39.

10. El Kady D, Gilbert WM, Xing G, et al. Maternal and neonatal outcomes of assaults during pregnancy. Obstetrics and Gynecology 2005;105(2):357-63.

11. Curry MA. The interrelationships between abuse, substance use, and psychosocial stress during pregnancy. Journal of Obstetric, Gynecologic, and Neonatal Nursing 1998;27(6):692-99.
12. Dietz PM, Gazmararian JA, Goodwin MM, et al. Delayed entry into prenatal care: effect of physical violence. Obstetrics and Gynecology 1997;90(2):221-24.

13. Moraes CL, Amorim AR, Reichenheim ME. Gestational weight gain differentials in the presence of intimate partner violence. International Journal of Gynecology and Obstetrics 2006;95(3):254-60.

14. Lau Y, Chan KS. Influence of intimate partner violence during pregnancy and early postpartum depressive symptoms on breastfeeding among Chinese women in Hong Kong. Journal of Midwifery and Women's Health 2007;52(2):15-20.

15. Bacchus L, Mezey G, Bewley S. Domestic violence: prevalence in pregnant women and associations with physical and psychological health. European Journal of Obstetrics and Gynecology and Reproductive Biology 2004;113(1):6-11.

16. Salari Z, Nakhaee N. Identifying types of domestic violence and its associated risk factors in a pregnant population in Kerman 
hospitals, Iran Republic. Asia-Pacific Journal of Public Health 2008;20(1):49-55.

17. Castro R, Peek-Asa C, Ruiz A. Violence against women in Mexico: a study of abuse before and during pregnancy. American Journal of Public Health 2003;93(7):1110-16.

18. Campbell J, Garcia-Moreno C, Sharps P. Abuse during pregnancy in industrialized and developing countries. Violence against Women 2004;10(7):770-89.

19. Sagrestano LM, Carrol D, Rodriguez AC, et al. Demographic, psychological, and relationship factors in domestic violence during pregnancy in a sample of low-income women of color. Psychology of Women Quarterly 2004;28(4):309-22.

20. Bailey BA, Daugherty RA. Intimate partner violence during pregnancy: incidence and associated health behaviors in a rural population. Maternal Child Health Journal 2007; 11(5):495-503.

21. Wiemann CM, Agurcia CA, Berenson $\mathrm{AB}$, et al. Pregnant adolescents: experiences and behaviors associated with physical assault by an intimate partner. Maternal and Child Health Journal 2000;4(2): 93-101.

22. Yost NP, Bloom SL, McIntire $\mathrm{DD}$, et al. A prospective observational study of domestic violence during pregnancy. Obstetrics and Gynecology 2005;106(1):61-65.

23. Goodwin MM, Gazmararian JA, Johnson $\mathrm{CH}$, et al. Pregnancy intendedness and physical abuse around the time of pregnancy: findings from the pregnancy risk assessment monitoring system, 1996-1997. Maternal Child Health Journal. [PRAMS Working Group. Pregnancy Risk Assessment Monitoring System] 2000;4(2):85-92.

24. Muhajarine N, D’Arcy C. Physical abuse during pregnancy: prevalence and risk factors. Canadian Medical Association Journal 1999; 160(7):1007-11.

25. Perales MT, Cripe SM, Lam N, et al. Prevalence, types, and pattern of intimate partner violence among pregnant women in Lima, Peru. Violence against Women 2009;15(2):224-50.

26. Ntaganira J, Muula AS, Masaisa $\mathrm{F}$, et al. Intimate partner violence among pregnant women in Rwanda. BMC Women's Health 2008;8(1).

27. Umeora OUJ, Dimejesi BI, Ejikeme BN, et al. Pattern and determinants of domestic violence among prenatal clinic attendees in a referral centre, South-east Nigeria. Journal of Obstetrics and Gynaecology 2008;28(8):769-74.

28. Rachana C, Suraiya K, Hisham AS, et al. Prevalence and complications of physical violence during pregnancy. European Journal of Obstetrics and Gynecology and Reproductive Biology 2002; 103(1):26-29.

29. Peedicayil A, Sadowski LS, Jeyaseelan L, et al. Spousal physical violence against women during pregnancy. British Journal of Obstetrics and Gynaecology 2004;111(7):682-87.

30. Karmaliani R, Irfan F, Bann CM, et al. Domestic violence prior to and during pregnancy among Pakistani women. Acta Obstetricia et Gynecologica Scandinavica 2008;87(11): 1194-01.

31. Fanslow J, Silva M, Robinson E, et al. Violence during pregnancy: associations with pregnancy intendedness, pregnancy-related care, and alcohol and tobacco use among a representative sample of New Zealand women. Australian and New Zealand Journal of Obstetrics and Gynaecology 2008;48:398-404.

32. Canterino JC, VanHorn LG,
Harrigan JT, et al. Domestic abuse in pregnancy: a comparison of a self-completed domestic abuse questionnaire with a directed interview. American Journal of Obstetrics and Gynecology 1999; 181(5):1049-51.

33. Moraes CL, Reichenheim ME. Domestic violence during pregnancy in Rio de Janeiro, Brazil. International Journal of Gynecology and Obstetrics 2002;79(3):269-77.

34. MEASURE DHS. DHS

Overview: ICF Macro; 2010.

At: <www.measuredhs.com/ aboutsurveys/dhs/start.cfm>.

35. MEASURE DHS. Ethical and Safety Guidelines for Implementing the DHS Domestic Violence Module. nd.

At: <www.measuredhs.com/ topics/gender/pdfs/ethical_ guidelines.pdf>.

36. World Health Organization. Putting women first: ethical and safety recommendations for research on domestic violence against women. Geneva: WHO Department of Gender and Women's Health; 2001.

37. UNICEF. State of the World's Children, 2009. New York: UNICEF; 2009.

38. Bacchus L, Mezey G, Bewley S. A qualitative exploration of the nature of domestic violence in pregnancy. Violence against Woman 2006;12(6):588-604.

39. Lau Y. Does pregnancy provide immunity from intimate partner abuse among Hong Kong Chinese women? Social Science and Medicine 2005;61(2):365-77.

40. Saltzman LE, Johnson CH, Gilbert BC, et al. Physical abuse around the time of pregnancy: an examination of prevalence and risk factors in 16 states. Maternal Child Health Journal 2003;7(1):31-43.

41. Ellsberg M, Heise L. Bearing witness: ethics in domestic violence research.

Lancet 2002;359(9317): 1599-1604. [doi: 10.1016/ S0140-6736(02)08521-5]. 
42. Stöckl H, Watts C, Kilonzo Mbwambo JK. Physical violence by a partner during pregnancy in Tanzania: prevalence and risk factors. RHM 2010;18(36): 171-80.

43. Pico-Alfonso MA, GarciaLinares MI, Celda-Navarro Blasco-Ros C, et al. The impact of physical, psychological and sexual intimate male partner violence on women's mental health: depressive symptoms, post-traumatic stress disorder, state anxiety and suicide. Journal of Women's Health 2006;15(5):599-611.

44. Duley L. The global impact of pre-eclampsia and eclampsia. Seminars in Perinatology 2009; 33:130-37.

45. Khan KS, Wojdyla D, Say L, et al. WHO analysis of causes of maternal death: a systematic review. Lancet 2006;367: 1066-74.

46. Bentley-Lewis R. Gestational diabetes mellitus: an opportunity of a lifetime [Comment]. Lancet 2009; 373:378-79.

47. Greenfield LA, Rand MR, Craven D. Analysis of data on crimes by current or former spouses, boyfriends, and girlfriends. Violence by
Intimates. Washington DC: US Dept of Justice; 1998.

48. Lewis G, editor. Confidential Enquiry into Maternal and Child Health. Saving Mothers' Lives: reviewing maternal deaths to make motherhood safer, 2003-2005. Seventh Report on Confidential Enquiries into Maternal Deaths in the United Kingdom. London: CEMACH; 2007.

49. Boy A, Salihu HM. Intimate partner violence and birth outcomes: a systematic review. International Journal of Fertility and Women's Medicine 2004;49(4):159-64.

\section{Résumé}

Nous souhaitions décrire la prévalence de la violence exercée sur les femmes enceintes par un partenaire intime dans 19 pays, et examiner les tendances par groupes d'âge et régions des Nations Unies. Nous avons mené une analyse secondaire des données d'enquêtes démographiques et sanitaires ( 20 enquêtes dans 15 pays) et d'enquêtes internationales sur la violence faite aux femmes (quatre enquêtes dans quatre pays) réalisées entre 1998 et 2007. Nos données indiquent que la violence du partenaire intime pendant la grossesse est fréquente. Sa prévalence allait d'environ 2,0\% en Australie, au Cambodge, au Danemark et aux Philippines à 13,5\% en Ouganda parmi les femmes ayant déjà été enceintes et ayant déjà eu un partenaire ; la moitié des enquêtes estimaient cette prévalence entre 3,9 et 8,7\%. La prévalence semblait plus élevée dans les pays d'Afrique et d'Amérique latine que dans les pays d'Europe et d'Asie ayant fait l'objet des enquêtes. Dans la plupart des pays, la prévalence était relativement constante dans les groupes d'âge les plus jeunes (15-35 ans) et semblait décliner très légèrement après 35 ans. La violence du partenaire intime pendant la grossesse est plus fréquente que certaines conditions de santé maternelle qui font l'objet d'un dépistage systématique dans les consultations prénatales. Les initiatives mondiales pour réduire la mortalité maternelle et améliorer la santé maternelle doivent consacrer davantage d'attention à la violence faite aux femmes, en particulier pendant la grossesse.

\section{Resumen}

Nos propusimos describir la prevalencia de violencia de pareja intima (VPI) durante el embarazo en 19 países y examinar las tendencias en diferentes grupos etarios y regiones de la ONU. Realizamos un análisis de datos secundarios de las Encuestas Demográficas y de Salud (20 encuestas de 15 países) y de las Encuestas Internacionales sobre Violencia contra las Mujeres (4 encuestas de 4 países) realizadas entre 1998 y 2007. Nuestros datos indican que la violencia de pareja intima durante el embarazo es una experiencia común. La prevalencia de la VPI durante el embarazo varió de un 2.0\% en Australia, Camboya, Dinamarca y Filipinas al 13.5\% en Uganda entre mujeres alguna vez embarazadas, que alguna vez tuvieron pareja; la mitad de las encuestas calcularon una prevalencia del 3.9\% al $8.7 \%$. La prevalencia pareció ser más alta en países africanos y latinoamericanos comparada con los países europeos y asiáticos encuestados. En la mayoría de los entornos, la prevalencia era relativamente constante en los grupos más jóvenes (de 15 a 35 años) y pareció disminuir muy poco después de los 35 años de edad. La violencia de pareja íntima durante el embarazo es más común que algunos problemas de salud materna para los cuales se hacen pruebas de detección sistemática durante la atención antenatal. Las iniciativas internacionales por disminuir la tasa de mortalidad materna y mejorar la salud materna deben dedicar mayor atención a la violencia contra las mujeres, particularmente la violencia durante el embarazo. 